\title{
Angiotensin II Type 1A Receptor Signaling Facilitates Tumor Metastasis Formation through P-Selectin-Mediated Interaction of Tumor Cells with Platelets and Endothelial Cells
}

\author{
Hideki Amano, ${ }^{*}$ Yoshiya Ito, ${ }^{*}$ Fumihiro Ogawa, ${ }^{\dagger}$ Koji Eshima ${ }^{\ddagger}$ Tatsunori Suzuki, ${ }^{*}$ Kazuhito Oba, ${ }^{*}$ Yoshio Matsui, ${ }^{*}$ \\ Shintaro Kato, ${ }^{*}$ Tomoya Fukui, ${ }^{*}$ Masaki Nakamura, ${ }^{\S}$ Hidero Kitasato, ${ }^{\S}$ Akiyoshi Fukamizu, ${ }^{\circledR}$ and Masataka Majima*
}

From the Departments of Pharmacology, ${ }^{*}$ Surgery,${ }^{\dagger}$ and Immunology, ${ }^{\ddagger}$ Kitasato University School of Medicine, Kanagawa; the Department of Microbiology, ${ }^{\S}$ Kitasato University School of Allied Health Science, Kanagawa; and the Center for Tsukuba Advanced Research Alliance, "Institute of Applied Biochemistry, University of Tsukuba, Ibaraki, Japan

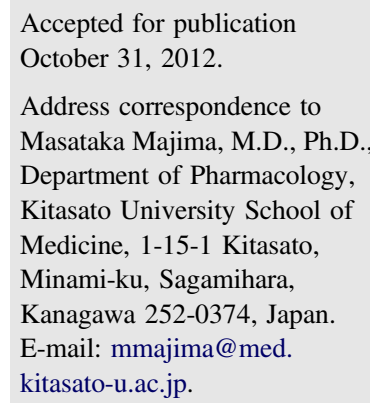

\begin{abstract}
Angiotensin II is involved in tumor growth; however, the precise mechanism is not known. Platelets also contribute to tumor growth, and angiotensin II type 1 receptor (AT1) is expressed on the platelet surface. We hypothesized that interaction of platelets with tumor cells through AT1 receptor signaling promotes tumor metastasis. B16F1 melanoma cells were intravenously injected into Agtr1a knockout mice $\left(A T 1 a^{-/-}\right)$and wildtype littermates (WT); the $A T 1 a^{-/-}$mice exhibited a reduction in lung colonies. Angiotensin II induced expression of P-selectin on platelets in WT but not in $\mathrm{ATI}^{-/-}$mice. A selective P-selectin neutralizing antibody decreased lung colony numbers in WT but not in $A T 1 a^{-/-}$mice. Levels of vascular endothelial growth factor (VEGF) and stromal cell-derived factor 1 (SDF-1) receptor in platelets at metastatic locus were lower in $A T 1 a^{-/-}$mice. Treatment of neutralizing antibodies against VEGF and CXCR4 decreased lung colony numbers in WT but not in $A T 1 a^{-/-}$mice. In $A T 1 a^{-/-}$mice, and both mobilization of progenitor cells expressing CXCR4 ${ }^{+}$VEGFR $1^{+}$cells from bone marrow and their recruitment to lung tissues were suppressed. These results suggest that AT1A signaling plays a critical role in tumor metastasis through P-selectin-mediated interactions of platelets with tumor and endothelial cells and through the AT1A signaling-dependent production of VEGF and SDF-1, which may be involved in mobilization of CXCR4 ${ }^{+}$VEGFR1 ${ }^{+}$cells. (Am J Pathol 2013, 182: 553-564; http://dx.doi.org/10.1016/j.ajpath.2012.10.026)
\end{abstract}

Tumor metastasis is a complex multistep process, requiring the acquisition of many distinct properties if it is to progress. Loss of cellular adhesion and increased invasiveness, intravasation, and survival and proliferation in a new site are all prerequisites for establishment of distant macrometastases. ${ }^{1-3}$ Despite progress in other areas of cancer therapeutics, the complexities of this process remain poorly understood.

Much evidence supports the concept that cancer metastasis is significantly facilitated by interaction between disseminating tumor cells and blood platelets. ${ }^{4}$ Interference by antiplatelet agents or anticoagulants in tumor cell-platelet interaction potently inhibit both spontaneous and experimental metastases. ${ }^{5}$ In addition, measures that lower circulating-platelet counts have resulted in a decrease in distant metastases. Platelets contain vascular endothelial growth factor (VEGF), stromal cell-derived factor-1 (SDF-1), fibroblast growth factor4 (FGF-4), and transforming growth factor (TGF), proteins that may be released into the peritumor space after platelet activation and influence tumor metastasis. ${ }^{6-10}$ These findings suggest that the interaction of activated platelets with tumor cells plays a critical role in the process of tumor metastasis.

The renin-angiotensin system plays important roles in the regulation of cardiovascular homeostasis and blood pressure. ${ }^{11}$ There is increasing evidence that angiotensin II (Ang II), which is generated by chymase or angiotensinconverting enzyme (ACE), in addition to its effects on blood pressure, may play a role in various pathological situations

Supported by research grants 12470529, 21390072, and 23592073 and by a High-Tech Research Center grant from the Japanese Ministry of Education, Culture, Sports, Science, and Technology, by the Graduate School of Medical Science Integrative Research Program, Kitasato University, and by a grant from the Uehara Memorial Foundation. 
involving regulation of cell proliferation, inflammation, angiogenesis, and tissue repair and development. ${ }^{12}$ Many reports have suggested that Ang II has a significant role as a growth factor. ${ }^{13-15}$ Other studies, including some from our research group, have also investigated the angiogenic effects of exogenous Ang II in several in vivo angiogenesis models. ${ }^{16-18}$ The pathophysiological activities of Ang II are known to be mediated by seven transmembrane receptors, and two major subtypes of Ang II receptors have been identified: AT1 and AT2, the former having subtypes A and B. ${ }^{19}$ Some recent studies using AT1 receptor antagonist and AT1A receptor-deficient mice [knockout of the Agtrla gene (alias ATla)] have shown that the blockade of AT1A receptor signaling inhibits growth of the following tumor cells: melanoma, lung, prostate, renal cell carcinoma, and pancreas. ${ }^{20-24}$ We have also found that the AT1 receptor antagonist TCV116, or a deficient gene for the AT1A receptor, inhibits tumor growth, tumor-associated angiogenesis, and metastasis in a murine model. ${ }^{17,21,25}$ However, the precise mechanisms regarding the contribution of AT1 receptor signaling to tumor metastasis remain to be determined.

Ang II has the effect of a potent angiogenesis stimulator, both directly and by supplying angiogenic factors by platelet aggregation. ${ }^{26}$ Platelets express AT1 receptors on their surface, and AT1 receptor antagonists reduce P-selectin expression in platelets $^{27}$ and inhibit P-selectin-mediated platelet adhesion to the microvessels. ${ }^{28}$ These findings led us to hypothesize that tumor metastasis is facilitated by interactions between platelets and metastatic tumor cells through AT1 receptor signaling. The objective of the present study was to investigate the role of AT1A signaling in colony formation and to explore the underlying mechanisms of tumor metastasis regulated by the AT1A signaling pathway.

\section{Materials and Methods}

\section{Animals}

Male C57BL/6 mice, 6 to 8 weeks old and weighing 25 to $30 \mathrm{~g}$, were obtained from the CLEA Japan Shizuoka Laboratory Animal Center (Fuji, Japan). AT1A receptor knockout mice $\left(\mathrm{ATla}^{-/-}\right)$on the $\mathrm{C} 57 \mathrm{BL} / 6$ hybrid background were generated by our research group. ${ }^{13}$ The mice (males, 8 weeks old) were maintained at a constant humidity $(60 \pm 5 \%)$ and temperature $\left(20 \pm 1^{\circ} \mathrm{C}\right)$ and were kept continuously on a 12-hour light/dark cycle. All animals were provided food and water ad libitum. All experiments were performed in accordance with the guidelines for animal experiments of Kitasato University School of Medicine.

\section{Tumor Metastasis Model}

B16F1 melanoma cells originally isolated from C57BL/6 mice were cultured at $37^{\circ} \mathrm{C}$ in RPMI 1640 medium suspended in $10 \%$ fetal bovine serum in a humidified atmosphere containing $5 \% \mathrm{CO}_{2} . \mathrm{B} 16 \mathrm{~F} 1$ cells were harvested and washed three times with PBS. The cells were suspended in PBS at a density of $3.0 \times 10^{6}$ cells $/ \mathrm{mL}$, and $100 \mu \mathrm{L}$ of the resulting suspension was injected into the tail vein. ${ }^{29}$ An AT1R antagonist, TCV-116 (100 mg/kg per day; Takeda Chemical Industries, Osaka, Japan), or an angiotensin-converting enzyme (ACE) agonist or Ang II was orally administrated every day (3.6 $\mu \mathrm{g} /$ day; Sigma-Aldrich, Tokyo, Japan). VEGF neutralized antibody $(10 \mu \mathrm{g}$ per mouse; Genzyme Japan, Tokyo, Japan), CXCR4 neutralized antibody (10 $\mu \mathrm{g}$ per mouse; clone 2B11; BD Biosciences, San Jose, CA), P-selectin neutralized antibody (30 $\mu \mathrm{g}$ per mouse; RB40.34; BD Biosciences), and isotype control $\operatorname{IgG}$ (rat $\mathrm{IgG}$ ) were intraperitoneally injected daily. On day 21 after injection of B16F1 cells, $A T 1 a^{-1-}$ and WT mice were sacrificed with ether, and the lungs were resected. The isolated lungs were fixed with Bouin's fluid solution, ${ }^{30}$ and metastatic colonies were counted under a light microscope. The numbers of white blood cells and platelet numbers were measured using a Celltac $\alpha$ automatic cell counter (MEK-6450; Nihon Kohden, Tokyo, Japan).

\section{Platelet Isolation}

Anesthetized WT C57BL/6 mice were bled via heart puncture into heparinized microtubes, and the blood was collected into acid citrate dextrose. Platelet-rich plasma (PRP) was obtained by centrifugation $(20 \times g$ for 20 minutes). The PRP was transferred to a fresh tube, platelets were centrifuged, and the pellet was resuspended in RPMI 1640 medium.

\section{Cell Culture}

B16F1 cells were maintained in RPMI 1640 medium containing 10\% fetal bovine serum. B16F1 cells (six-well tissue culture plates at $3 \times 10^{5}$ cells per well) were incubated with platelets $\left(1.0 \times 10^{5}\right.$ per well). Tumor cells and platelets were stimulated with Ang II $(10 \mu \mathrm{g} / \mathrm{mL}$ per well) and P-selectin antibody $(10 \mu \mathrm{g} / \mathrm{mL}$ per well) for 6 hours.

Measurement of VEGF, SDF-1, SCF, and Pro-MMP-9 Levels

To determine plasma levels of VEGF, SDF-1, and stem cell factor (SCF) and bone marrow (BM) levels of pro-matrix metallopeptidase 9 (pro-MMP-9), plasma and BM via the femur were collected and stored at $-20^{\circ} \mathrm{C}$ until assay. Plasma levels of VEGF, SDF-1, and SCF and BM levels of proMMP-9 were assessed with specific enzyme-linked immunosorbent assay (ELISA) kits (R\&D Systems, Minneapolis, MN). We also measured VEGF and SDF-1 in PRP and cell culture supernatants with ELISA kits. These experiments were performed in duplicate.

\section{Preparation of Lung Tissue for ELISA}

After lung tissues were extracted, tissues were rinsed in icecold PBS $(0.02 \mathrm{~mol} / \mathrm{L}, \mathrm{pH} 7.0$ to 7.2$)$ to remove excess blood thoroughly and were weighed before homogenization. Tissues were minced into small pieces and then were 
homogenized in $1 \mathrm{~mL}$ of PBS with homogenizer on ice. The resulting suspension was sonicated with an ultrasonic cell disrupter, and the homogenates were centrifuged for 5 minutes at $5000 \times g$. Supernatants were used to measure VEGF, SDF-1, and PSGL-1 (mouse PSGL-1 ELISA kit; USCN Life Science, Houston, TX). All levels were normalized to total protein concentrations as determined by BCA assay (Pierce; Thermo Fisher Scientific, Rockford, IL).

\section{Flow Cytometric Analysis}

Blood was drawn via the tail vein on day 1 after surgery. The white blood cell fraction, including platelets, was obtained by Ficoll separation, and flow cytometric analysis was performed as described previously. ${ }^{31,32}$ In another set of experiments, platelets $\left(1.0 \times 10^{5}\right.$ per well) were incubated in RPMI 1640 medium for 24 hours and then were treated with Ang II $(10 \mu \mathrm{g} / \mathrm{mL}$ per well) for 30 minutes. Cells were labeled with fluorescein isothiocyanate anti-mouse CD41 antibody (eBioscience, San Diego, CA) and phycoerythrinlabeled anti-mouse P-selectin antibody or fluorescein isothiocyanate-labeled anti-VEGFR1 and phycoerythrinlabeled anti-CXCR4 isotype control antibody (BD Pharmingen, San Diego, CA), in the presence of an anti-FcR monoclonal antibody (2.4G2; BD Biosciences). After a washing, the cells were analyzed with a FACSCalibur flow cytometer (BD Biosciences), and small cells (with low forward scatter) were gated for peripheral blood analysis.

\section{Immunohistochemical Studies}

For immunofluorescent cytochemistry, lung tissues were immediately fixed with $4 \%$ paraformaldehyde in a $0.1 \mathrm{~mol} / \mathrm{L}$ phosphate buffer solution ( $\mathrm{pH}$ 7.4). After fixation, the tissues were dehydrated with a graded ethanol series and then embedded in paraffin. Sections of the paraffin-embedded tissues ( $4 \mu \mathrm{m}$ thick) were mounted on glass slides, deparaffinized with xylene, and placed in $4^{\circ} \mathrm{C}$ acetone. The sections were blocked with $1 \%$ bovine serum albumin-PBS and incubated with anti-mouse CXCR4 antibody (1:200; LifeSpan Biosciences, Seattle, WA), anti-mouse VEGFR-1 antibody (1:200; Santa Cruz Biotechnology, Santa Cruz, CA), mouse anti-human integrin $\alpha \mathrm{IIb}$ monoclonal antibody (1:50; Santa Cruz Biotechnology), rabbit anti-rat VEGF antibody (1:500; Santa Cruz Biotechnology), goat anti-human SDF antibody (1:100; Santa Cruz Biotechnology), and anti-mouse P-selectin antibody (1:50; BD Pharmingen). After a washing in PBS, the sections were incubated with Alexa Fluor 488 goat anti-rabbit IgG (1:1000; Invitrogen; Life Technologies, Carlsbad, CA) and Alexa Fluor 568 goat anti-rat $\operatorname{IgG}$ (1:1000; Invitrogen; Life Technologies). Negative control staining was performed by replacing the primary antibodies with $1 \%$ bovine serum albumin-PBS. Images were captured with a confocal scanning laser microscope (LSM710; Carl Zeiss, Jena, Germany), as described previously. ${ }^{33,34}$

\section{Immunofluorescence Analysis in Cultured Cells}

B16F1 and human umbilical vein endothelial cells (HUVECs) were grown from 50\% to 60\% confluent cultures on Lab-Tek II chamber slides (Nalge Nunc International; Thermo Scientific, Rochester, NY). The monolayers were fixed with $3.7 \%$ paraformaldehyde for 10 minutes, permeabilized in $0.2 \%$ Triton X-100 for 10 minutes, and then incubated with anti-PSGL-1 goat polyclonal antibody (1:100; Santa Cruz Biotechnology) overnight. The secondary antibody was Alexa Fluor 568-conjugated donkey anti-goat IgG (Invitrogen; Life Technologies). Sections were then observed under a confocal scanning laser microscope.

\section{Real-Time RT-PCR}

Transcripts encoding PSGL-1 and glyceraldehyde-3phosphate dehydrogenase (GAPDH) were quantified by real-time RT-PCR analysis. After 2 hours of treatment with Ang II, HUVECs were collected and homogenized with TRIzol reagent. The real-time RT-PCR primers were designed using Primer 3 software (http://primer3.source forge.net) on the basis of data from GenBank. The following primers were used for real-time RT-PCR: PSGL-1, 5'-GAGAAGATTGCCACCACTGAC-3' (sense) and $5^{\prime}$ GTTGGACGGTCTCTACTGAGG-3' (antisense); GAPDH, 5'-ACATCAAGAAGGTGGTGAAGC-3' (sense) and $5^{\prime}$ AAGGTGGAAGAGTGGGAGTTG-3' ${ }^{\prime}$ (antisense); human PSGL-1， 5'-CAATTTGTCCGTCAACTACCC-3' (sense) and $5^{\prime}$-TGCACACGAAGAAGATAGTGG- $3^{\prime}$ (antisense); human P-selectin, 5'-GCCAGAATGAATACGTGAG-3' (sense) and $5^{\prime}$-AGCTGCACTGCGAGTTAAAG-3' (antisense); and human GAPDH, 5'-GAAGGTGAAGGACGGACTC-3' (sense) and 5'-GAAGATGGTGATGGGATTTC-3' (antisense) (Sigma-Aldrich).

\section{Western Blot Assays}

Total cellular proteins were isolated using radioimmunoprecipitation assay buffer $[50 \mathrm{mmol} / \mathrm{L}$ Tris- $\mathrm{HCl}(\mathrm{pH} 7.2)$, $1 \%$ Nonidet P-40, $0.5 \%$ sodium deoxycholate, $0.1 \%$ sodium dodecyl sulfate]. Nuclear and cytoplasmic fractions were also prepared using NE-PER nuclear and cytoplasmic extraction reagents (Pierce; Thermo Fisher Scientific). Aliquots of 1 to $10 \mu \mathrm{g}$ of protein were resolved by SDS-PAGE and transferred to membranes. Immunoblotting was performed with mouse polyclonal anti-PSGL-1 antibody (1:400; Abnova, Taipei, Taiwan) and monoclonal anti-mouse $\beta$-actin (1:10000; SigmaAldrich), followed by incubation with anti-rabbit horseradish peroxidase conjugated secondary antibody (1:2000; GE Healthcare, Little Chalfont, UK), and anti-mouse horseradish peroxidase conjugated secondary antibody (1:2000; GE Healthcare). The protein was visualized by a commercial chemiluminescent method with an Amersham ECL detection system (GE Healthcare). 


\section{BM Transplantation}

BM transplantation was performed as reported previously. ${ }^{35}$ Donor BM cells from $\mathrm{ATla}^{-1-}$ mice and their WT counterparts were harvested using the same method. The BM mononuclear cells of each donor $\left(2.0 \times 10^{6}\right.$ cells in $200 \mathrm{~mL}$ PBS) were transplanted via the tail veins of irradiated WT.

\section{Statistical Analysis}

Data are expressed as means \pm SD. Comparisons among multiple groups were performed by analysis of variance. Comparisons between the two groups were made using Student's $t$-test. Survival experiments were analyzed using the log-rank test and are presented as Kaplan-Meier survival curves. $P<0.05$ was considered statistically significant.

\section{Results}

\section{AT1A Signaling Promotes Lung Metastasis Formation}

We examined the effect of the AT1 antagonist TCV-116 on lung metastasis after i.v. injection of $\mathrm{B} 16 \mathrm{~F} 1$ cells into mice. The number of lung colonies in mice treated with the AT1 antagonist was significantly lower than in control mice: TCV-116, $45.8 \pm 18.9$ colonies; PBS, $98.7 \pm 17.0$ colonies $(P<0.01)$ (Figure 1A). In contrast, mice treated with Ang II exhibited significantly induced colony formation, compared with PBStreated mice: Ang II, $128.6 \pm 13.3$ colonies; PBS, $98.7 \pm$ 17.0 colonies $(P<0.05)$. These results suggest that AT1 plays an important role for lung metastasis in this model.

We have previously reported that AT1A receptor signaling is a key regulator of tumor associated angiogenesis and tumor growth. ${ }^{21}$ To investigate the role of AT1A signaling in tumor metastasis, we compared the numbers of lung colonies in $A T I a^{-/-}$mice with those in WT mice (Figure 1B). There were significantly fewer colonies formed in $A T 1 a^{-/-}$than in WT mice: WT, $116.2 \pm 25.9$ colonies; $A_{T l a}{ }^{-1-}, 45.8 \pm 18.9$ colonies $(P<0.05)$ (Figure 1C). In addition, on day 21 after injection of tumor cells, almost all of the WT mice had died, whereas all of the $A T 1 a^{-1-}$ mice survived (Figure 1D). These results suggest that AT1A signaling facilitates $\mathrm{B} 16 \mathrm{~F} 1$ lung colony formation and is also a prognostic factor for metastasis.

\section{Changes in the Number of Platelets during Lung Metastasis}

Because platelets may play a role in tumor metastasis formation, we determined platelet numbers during the formation of lung metastasis. Baseline numbers did not differ between WT and $A T 1 a^{-1-}$ mice $(P>0.172)$. On days 7 and 14 , however, platelet numbers were significantly decreased in $A T I a^{-/}$ mice, compared with WT mice: $75.8 \times 10^{4} \pm 1.54 / \mu \mathrm{L}$ for $A T 1 a^{-/-}$mice versus $107.6 \times 10^{4} \pm 1.45 / \mu \mathrm{L}$ for WT mice on day 7 , and $71.0 \times 10^{4} \pm 1.23 / \mu \mathrm{L}$ for $A T 1 a^{-1-}$ mice versus
A

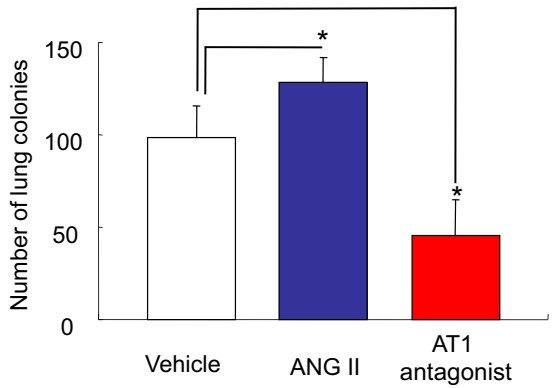

B
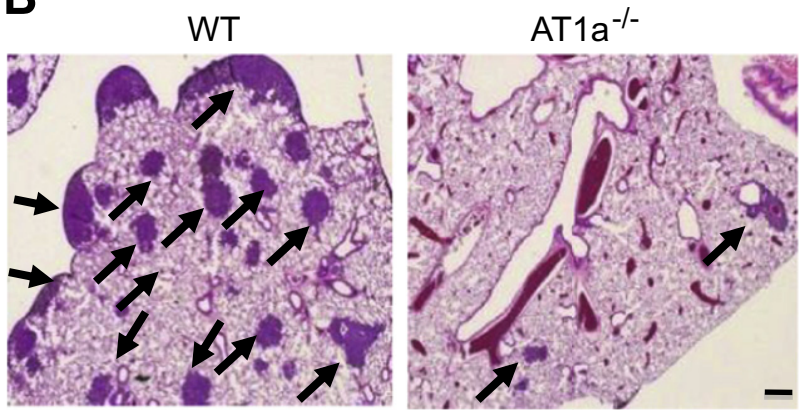

C

D
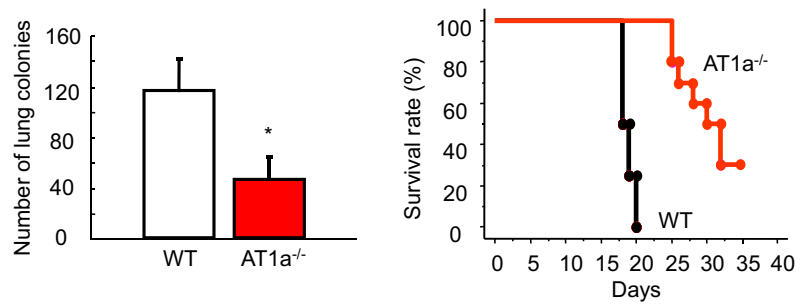

Figure 1 Ang II (AT1A) receptor signaling enhances lung colony formation. A: Effects of Ang II and of the AT1 antagonist TCV-116 on lung colony formation on day 14 after i.v. injection of B16F1 cells. B: Typical appearance of $\mathrm{H} \& \mathrm{E}$ staining of metastatic lung tumors from WT and $A T 1 a^{-/-}$ mice on day 14 after i.v. injection of B16F1 cells. The metastatic area is indicated by arrows. C: Number of lung colonies from WT and $A T 1 a^{-/-}$mice on day 14 after i.v. injection of B16F1 cells. D: Mortality after i.v. injection of B16F1 cells. The survival rate in WT mice was lower than that in $A T 1 a^{-/-}$mice. Survival was monitored on a daily basis. Data are expressed as means $\pm S D$ $(\mathbf{A}$ and $\mathbf{C}) . n=6(\mathbf{A})$ or $10(\mathbf{C})$ mice per group. ${ }^{*} P<0.05$ versus vehicletreated mice $(\mathbf{A}) ;{ }^{*} P<0.05$ versus WT, Student's $t$-test $(\mathbf{C})$; and ${ }^{*} P<0.05$ versus WT, Kaplan-Meier analysis (D). Scale bar $=130 \mu \mathrm{m}$.

$99.8 \times 10^{4} \pm 1.46 / \mu \mathrm{L}$ for WT mice on day $14(P<0.05)$ (Figure 2A). These results suggest that increased platelet numbers are associated with enhanced colony formation through AT1A signaling.

\section{Involvement of Ang II/AT1A in P-Selectin Expression on Platelets}

To examine whether Ang II induces platelet activation, we lisolated platelets from WT and $A T 1 a^{-/}$mice. The platelets were then incubated for 30 minutes under Ang II stimulation, and the expression of P-selectin (CD62P) ${ }^{+} \mathrm{CD} 41^{+}$platelets was determined. The percentage of $\mathrm{CD} 2 \mathrm{P}^{+} \mathrm{CD} 41^{+}$platelets in Ang II-treated WT mice was 
A
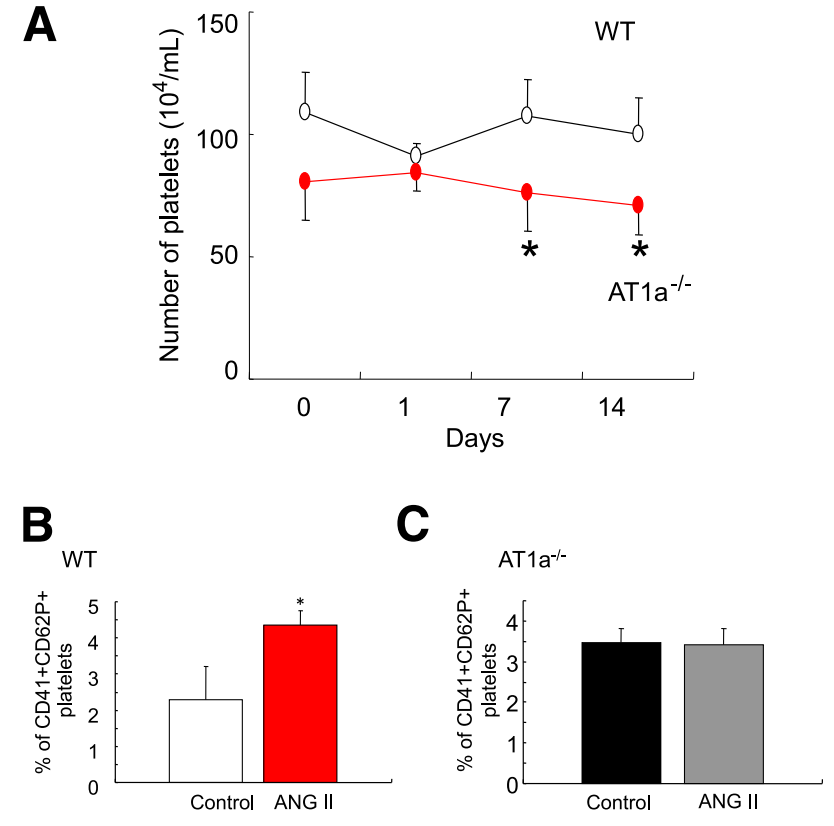

D

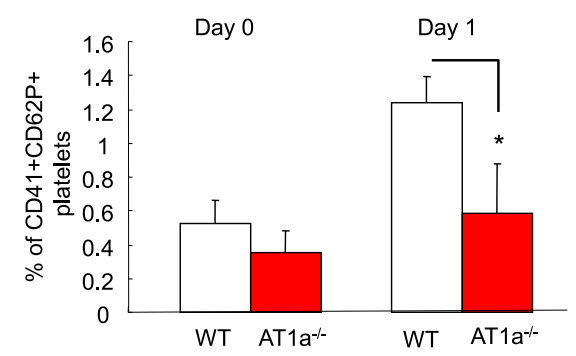

Figure 2 Effect of Ang II and AT1A signaling on platelet activation. A: Changes in platelet numbers in WT and $A T 1 a^{-/-}$mice after injection of B16F1 cells. B and C: Percentage of $\mathrm{CD}^{-} 1^{+} / \mathrm{CD}^{-} \mathrm{P}^{+}$platelets from WT (B) and $\mathrm{ATIa}^{-/-}$(C) mice after Ang II stimulation. Isolated platelets $(1.0 \times$ $10^{5}$ per well) were stimulated with Ang II $(10 \mu \mathrm{g} / \mathrm{mL}$ per well) in vitro. D: Reduced percentage of $\mathrm{CD}_{1} 1^{+} / \mathrm{CD} 62 \mathrm{P}^{+}$platelets in the peripheral blood of WT and $A T 1 a^{-/-}$mice on day 1 after injection of B16F1 cells. Data are expressed as means \pm SD. $n=10$ mice per group $(\mathbf{A})$ or 5 mice per group $(\mathbf{B}-\mathbf{D}) .{ }^{*} P<0.05$ versus WT $(\mathbf{A}$ and $\mathbf{D})$ or versus control (B and $\left.\mathbf{C}\right)$, Student's $t$-test.

significantly enhanced, compared with PBS-treated WT mice $(P<0.05)$ (Figure 2B). In contrast, for the $A T l a^{-1-}$ mice platelets did not differ significantly between the Ang II and PBS treatments (Figure 2C). These results suggest that AT1A receptor signaling on platelets is required for Ang II-induced P-selectin expression.

Platelets activated by Ang II would interact with tumor cells as well as endothelial cells. To further examine whether AT1A signaling affects platelet activity during tumor metastasis formation, the population of $\mathrm{CD} 62 \mathrm{P}{ }^{+} \mathrm{CD} 41^{+}$platelets was determined by flow cytometry analysis. The percentage of $\mathrm{CD}_{2} 2 \mathrm{P}^{+} \mathrm{CD} 41^{+}$platelets in $A T 1 a^{-/-}$mice on day 1 was significantly reduced, compared with WT mice: $A T 1 a^{-/-}$, $0.58 \pm 0.29 \%$; WT, $1.27 \pm 0.18 \%(P<0.05)$ (Figure 2D). This result suggests that AT1A signaling plays a role in platelet activation during the initial step of lung metastasis.
AT1A Signaling Regulates Involvement of P-Selectin in Tumor Metastasis and Adhesion of Platelets to Tumor Cells

To investigate the interaction of platelets with tumor cells at the metastatic sites, double-immunostaining analysis of P-selectin with integrin $\alpha \mathrm{IIb}$, a specific marker for platelets, was performed. The expression of P-selectin was colocalized with cells positive for $\alpha \mathrm{IIb}$ around the metastatic area, and coexpression of $\mathrm{P}$-selectin and $\alpha \mathrm{IIb}$ was reduced in $A T l a^{-1-}$ mice, compared with WT mice (Figure 3A). These results indicate that AT1A signaling induces metastasis formation via interaction of activated platelets with tumor cells. To clarify the role of P-selectin in tumor metastasis formation via AT1A signaling, P-selectin neutralizing antibody was injected. In WT mice, treatment with P-selectin neutralizing antibody markedly reduced the number of lung colonies, compared with $\mathrm{IgG}$ treatment: P-selectin neutralizing antibody, $53.6 \pm 18.5$ colonies; $\mathrm{IgG}, 118.2 \pm 23.1$ colonies $(P<0.05)$. In the $A T 1 a^{-1-}$ mice, however, there was no difference in the number of lung colonies formed: $P$-selectin neutralizing antibody, $46.6 \pm 19.2$ colonies; $\mathrm{IgG}, 35.4 \pm 10.1$ colonies $(P>0.4)$ (Figure $3 \mathrm{~B})$. These results suggest that P-selectin-mediated tumor metastasis formation is AT1A signaling dependent.

We further examined whether the interaction of platelets with tumor cells is involved in P-selectin-mediated lung colony formation. Immunohistochemical analysis revealed intense staining for the platelet integrin $\alpha \mathrm{IIb}$ in the metastatic locus in WT mice (Figure 3C), and an antibody against P-selectin attenuated the expression of $\alpha$ IIb in the metastatic tumor (Figure 3C). In $\mathrm{ATla}^{-/-}$mice, the expression of $\alpha \mathrm{IIb}$ was less marked, compared with WT mice (Figure 3C). An antibody against $\mathrm{P}$-selectin failed to affect expression of $\alpha \mathrm{Ilb}$ in $\mathrm{ATla}^{-/-}$mice (Figure 3C). These results suggest that lung colony formation can be attributed to P-selectin-mediated interaction of platelets with tumor cells and that AT1A signaling plays a critical role in the P-selectin-mediated platelet attachment to the metastatic tumor locus.

Ang II Enhances Expression of PSGL-1 in B16F1 Cells, Endothelial Cells, and Lung Tissue

P-selectin glycoprotein ligand-1 (PSGL-1) is a major ligand for P-selectin, and therefore we analyzed the expression of PSGL-1. The B16F1 cells expressed PSGL-1 (Figure 4A).

Gene expression and protein expression of PSGL-1 were enhanced by stimulation with Ang II (Figure 4B). Endothelial cells also express PSGL-1, and both gene expression and protein expression of PSGL-1 were detected in HUVECs (Figure 4C). Treatment with Ang II significantly enhanced the expression of PSGL-1, compared with control (Figure 4D). Furthermore, PSGL-1 concentrations in lung tissue were significantly decreased in $\mathrm{ATla}^{-/}$mice, compared with WT mice: WT, $9.35 \pm 1.57 \mathrm{ng} / \mathrm{mg}$ protein; $A T l a^{-1-}, 5.88 \pm 2.06 \mathrm{ng} / \mathrm{mg}$ protein $(P<0.05)$ (Figure 4E). In contrast, the expression of P-selectin in 
A

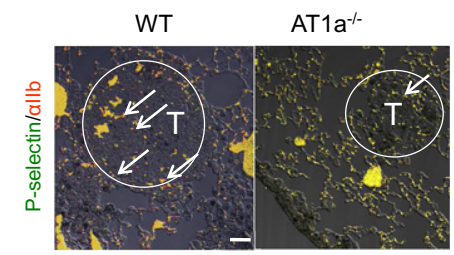

B

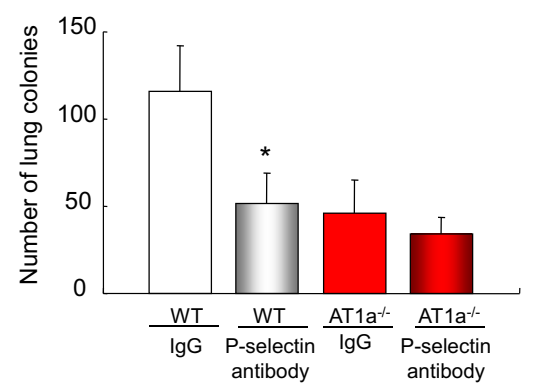

C H\&E allb

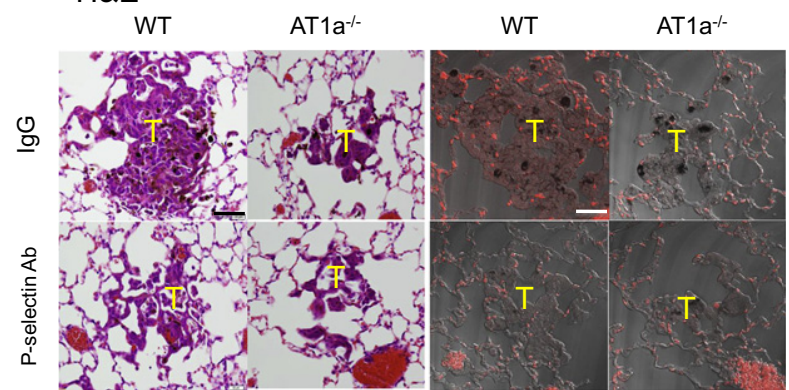

Figure 3 Effects of P-selectin on lung colony formation and platelet accumulation in the metastatic area. A: Accumulation of P-selectin-positive platelets was reduced in the metastatic area in $A T 1 a^{-/-}$mice on day 7 after injection of B16F1 cells. Double-staining of lung sections from WT and $A T 1 a^{-/-}$mice with antibodies against P-selectin (green) and $\alpha \mathrm{IIb}$ (red). Double-labeled cells are indicated by arrows. B: Neutralization of P-selectin monoclonal antibody reduced the number of colony formation in WT but not in $A T 1 a^{-/-}$mice. C: P-selectin neutralizing antibody reduced the localization of integrin $\alpha \mathrm{IIb}$ (red) in the metastatic area in WT but not in $A T 1 a^{-/-}$mice. H\&E-stained sections (left columns) correspond to immunostained sections (right columns) of lung tissue. The metastatic area is marked as tumor (T). Data are expressed as means \pm SD. $n=5$ mice per group. ${ }^{*} P<0.05$ versus IgG-treated mice. Scale bars: $50 \mu \mathrm{m}(\mathbf{A})$; $100 \mu \mathrm{m}(\mathbf{C})$.

HUVECs was reduced by Ang II treatment (Figure 4F). The finding that Ang II enhanced the expression of PSGL-1 on B16F1 melanoma cells as well as endothelial cells suggests that P-selectin expressed on platelets could bind to PSGL-1 on both tumor cells and endothelial cells.

\section{AT1A Signaling Increases Lung Colonies via VEGF and SDF-1}

On activation, platelets release proangiogenic factors, including VEGF and SDF-1, and these factors are involved in tumor metastasis formation. ${ }^{21}$ We therefore determined the plasma levels of VEGF and SDF-1 in $A T 1 a^{-/-}$and WT mice. Plasma levels of VEGF in $A T 1 a^{-/-}$mice $(35.2 \pm 5.49 \mathrm{pg} / \mathrm{mL})$ on day 7 after injection of B16F1 cells was found to be lower than that in WT mice $(45.7 \pm 2.63 \mathrm{pg} / \mathrm{mL})$. In addition, the levels of SDF-1 in $A T l a^{-1-}$ mice were decreased, compared with WT mice (Figure 5, A and B). We also measured levels of VEGF and SDF-1 in lung tissue on day 7. Both VEGF and SDF-1 levels in lung tissue from $A T 1 a^{-/-}$mice $(50.36 \pm 11.64 \mathrm{pg} / \mathrm{mg}$ protein and $12.5 \pm 2.46 \mathrm{pg} / \mathrm{mg}$ protein, respectively) were significantly suppressed, compared with WT mice $(67.78 \pm 9.39 \mathrm{pg} / \mathrm{mg}$ protein and $19.94 \pm 5.47 \mathrm{pg} / \mathrm{mg}$ protein, respectively) $(P<$ 0.05) (Figure 5, C and D). These results suggest that AT1A signaling is important for tumor metastatic formation through its involvement in the production of VEGF and SDF-1.

To estimate whether VEGF and SDF-1 were derived from platelets, double-immunostaining analysis was performed. Double-immunostaining analysis revealed that both VEGFexpressing cells and SDF-expressing cells were positive for $\alpha \mathrm{IIb}$ and were located around the metastatic tumor. The numbers of colocalized cells were dramatically reduced in $A T l a^{-/-}$mice, compared with WT mice (Figure 5C). These results suggest that AT1A signaling increases VEGF and SDF-1 from platelets and metastasis formation. To verify
A

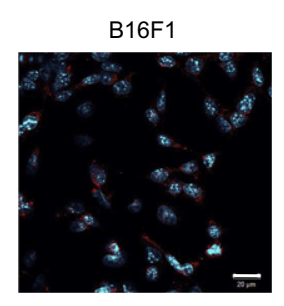

C

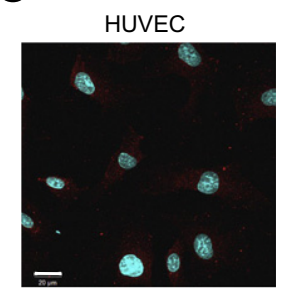

$\mathbf{E}$

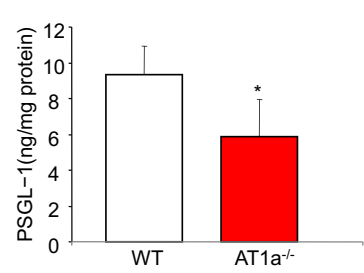

B

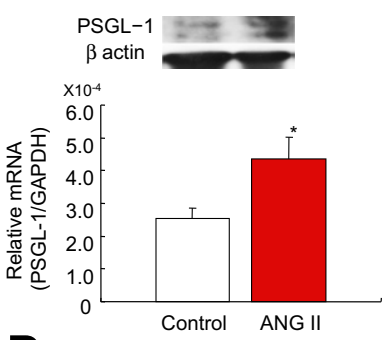

D

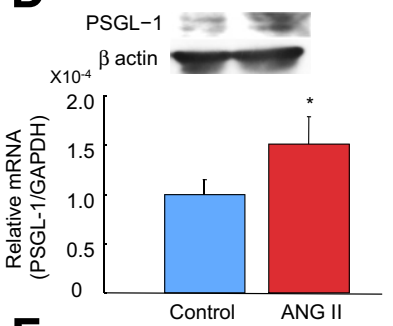

$\mathbf{F}$

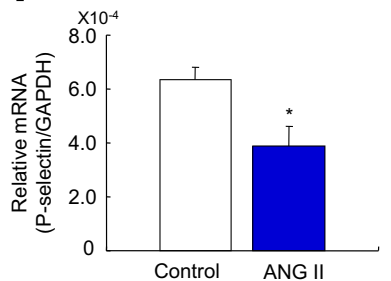

Figure 4 Ang II enhances PSGL-1 expression on tumor cells and endothelial cells. A and C: Immunofluorescence analysis against PSGL-1 (red) on B16F1 cells (A) and HUVECs (C). B and D: Expression of PSGL-1 on B16F1 cells (B) and HUVECs (D) stimulated with Ang II. Immunoblots show protein expression of PSGL-1. E: Effects of Ang II on PSGL-1 mRNA expression on HUVECs. F: Expression of PSGL-1 in lung tissue from WT and AT1 $a^{-/-}$mice on day 14 after injection of B16F1 cells. PSGL-1 expression was determined by ELISA. Data are expressed as means \pm SD. $n=5$ mice per group (B and $\mathbf{F}$ ) or 4 mice per group ( $\mathbf{D}$ and $\mathbf{E})$. ${ }^{*} P<0.05$ versus control, Student's $t$-test. Scale bar $=20 \mu \mathrm{m}$. Original magnification, $\times 400$. 
the functional role of VEGF and SDF-1 in tumor metastasis, we treated WT mice with neutralizing antibodies against VEGF and CXCR4, a receptor for SDF-1. Treatment of WT mice with VEGF neutralizing antibody markedly reduced the number of lung colonies, compared with the IgG treatment: VEGF neutralizing antibody, $53.6 \pm 18.5$ colonies; $\mathrm{IgG}, 118.2 \pm 23.1$ colonies $(P<0.05)$ (Figure 5D). In $A T 1 a^{-1-}$ mice, however, there was no difference in the number of lung colonies formed between the two treatments: VEGF neutralizing antibody, $46.6 \pm 19.2$ colonies; $\mathrm{IgG}, 35.4 \pm 10.1$ colonies $(P>0.05)$. Furthermore, treatment of WT mice with CXCR4 neutralizing antibody markedly reduced the number of lung colonies, compared with IgG treatment: CXCR4 antibody, $53.6 \pm 18.5$ colonies; $\mathrm{IgG}, 118.2 \pm 23.1$ colonies $(P<0.05)$. In $\mathrm{ATla}^{-1-}$ mice, however, there was no difference in the number of lung colonies formed between the two treatments: CXCR4 antibody treatment, $46.6 \pm 19.2$ colonies; IgG-treated $A T l a^{-/-}$ mice, $35.4 \pm 10.1$ colonies $(P>0.05)$.

\section{VEGF and SDF-1 Are Released from Platelets through} Interaction with Tumor Cells

To verify that platelets release VEGF and SDF-1 through interaction with tumor cells, platelets were incubated with tumor cells (B16F1 cells) in vitro, and the levels of VEGF and SDF-1 in cell supernatants were determined by ELISA (Figure 6, A and B). Platelets incubated with tumor cells significantly increased VEGF levels $(91.92 \pm 13.22 \mathrm{pg} / \mathrm{mL})$, compared with levels in tumor cells alone ( $47.46 \pm 11.68 \mathrm{pg} /$ $\mathrm{mL}$ ) (Figure 6A). Platelets activated by Ang II and incubated with tumor cells further increased the levels of VEGF by 1.8fold $(161.92 \pm 16.84 \mathrm{pg} / \mathrm{mL})$. This increase was completely blocked by P-selectin antibody, suggesting that elevated levels of VEGF were derived from activated platelets, because no elevation of VEGF was found in Ang II-stimulated tumor cells alone. The same was true for SDF-1 (Figure 6B), demonstrating that the levels of SDF-1 from platelets with tumor cells $(1.03 \pm 0.16 \mathrm{ng} / \mathrm{mL})$ were

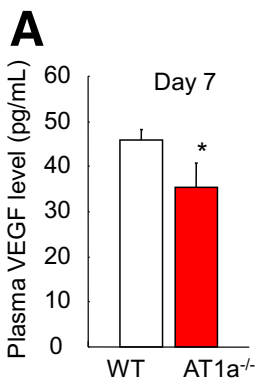

B

$\mathbf{E}$

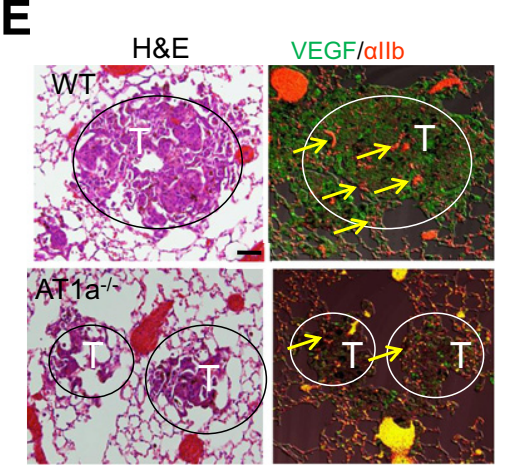

G

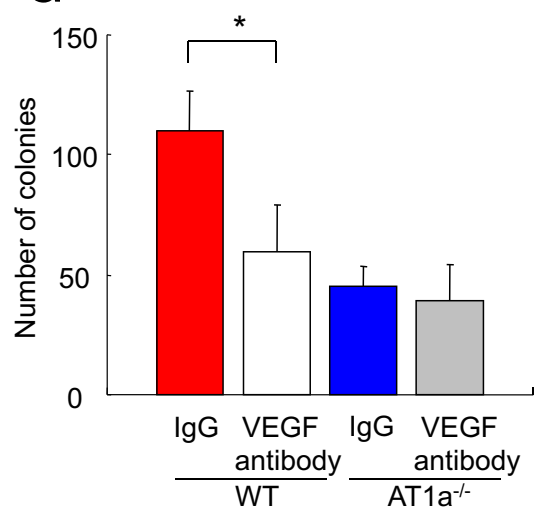

C

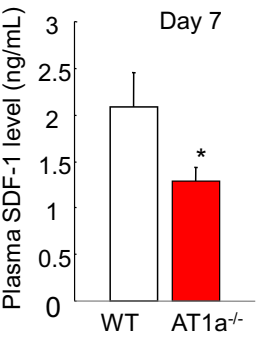

$\mathrm{F}$

F

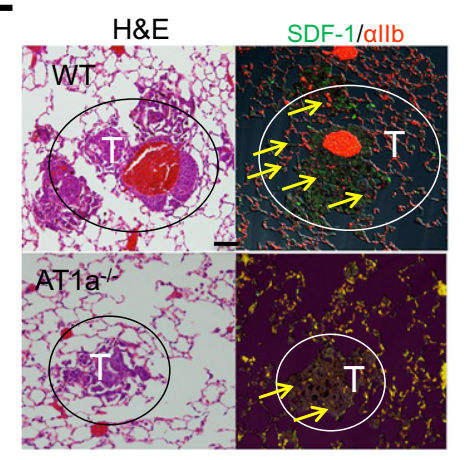

H

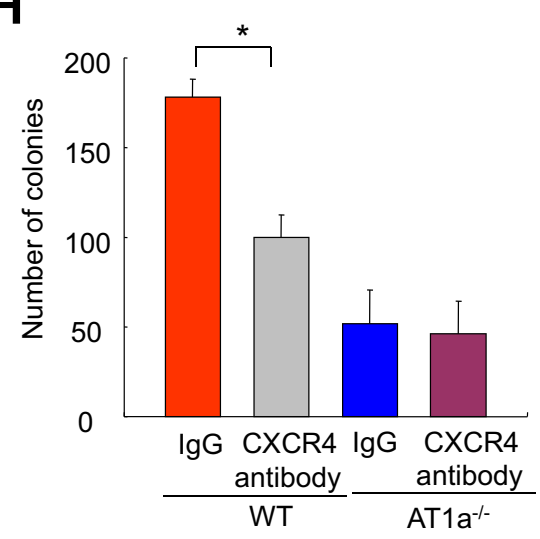

Figure 5 Levels of VEGF-A and SDF-1 in plasma, lung tissue, and pulmonary metastatic lesion and the effect of neutralizing antibodies against VEGF and CXCR4 on lung colonization. $\mathbf{A}$ and $\mathbf{B}$ : Plasma level of VEGF-A (A) and SDF-1 (B) in peripheral blood on day 7 after injection of B16F1 cells. $C$ and D: Pulmonary tissue level of VEGF-A (C) and SDF-1 (D) on day 14 after injection of B16F1 cells. E and $\mathbf{F}$ : Lung expression of VEGF/ $\alpha \mathrm{IIb}(\mathrm{E})$ and SDF$1 / \alpha I I b(F)$ on day 7 after injection of B16F1 cells in WT and $A T 1 a^{-/-}$mice. H\&E staining (left column) corresponds to double immunostaining (right column) of lung sections from WT and $A T 1 a^{-/-}$ mice with antibodies against VEGF (green) and $\alpha \mathrm{IIb}$ (red) (E) or SDF-1 (green) and $\alpha \mathrm{IIb}$ (red) (F). The metastatic area is outlined in white and marked with a T. Double-labeled cells are indicated by arrows. Images are representative of three independent samples. $\mathbf{G}$ and $\mathbf{H}$ : Treatment with neutralizing antibody against VEGF (G) and CXCR4 $(H)$ reduced the number of colony formation in WT but not in $\mathrm{AT}_{1} \mathrm{a}^{-/-}$mice after injection of B16F1 cells. Data are expressed as means \pm SD. $n=5$ mice per group. ${ }^{*} P<0.05$ versus WT mice $(A-D)$ or versus IgG-treated mice ( $\mathrm{G}$ and $\mathrm{H})$, Student's $t$-test. Scale bar $=50 \mu \mathrm{m}$. 
raised by addition of Ang II (to $1.67 \pm 0.43 \mathrm{ng} / \mathrm{mL}$ ) and that P-selectin antibody reduced these increased levels (to $1.05 \pm$ $0.16 \mathrm{ng} / \mathrm{mL}$ ). These results indicate that platelets stimulated with Ang II release SDF-1 during interaction with tumor cells.

Treatment with P-selectin antibody reduced tumor metastasis associated with reduction in platelet attachment (Figure 3D), suggesting that lung colony formation can be attributed to P-selectin-mediated interaction of platelets with tumor cells. To further examine whether platelets release VEGF and SDF-1 during interaction with tumor cells in vivo, we measured the levels of VEGF and SDF-1 in PRP from mice treated with P-selectin antibody or IgG on day 7 after injection of tumor cells (Figure 6, C and D). Levels of VEGF in PRP from WT mice treated with P-selectin antibody $(98.86 \pm 12.75$ $\mathrm{pg} / \mathrm{mL}$ ) were significantly decreased, compared with $\mathrm{IgG}$ $(161.23 \pm 26.22 \mathrm{pg} / \mathrm{mL})$; in $A T l a^{-1-}$ mice, however, there was no difference in VEGF levels between treated and IgG control mice: P-selectin antibody, $91.75 \pm 12.36 ; \mathrm{IgG}, 72.11 \pm 23.84$ $\mathrm{pg} / \mathrm{mL}(P=0.253)$ (Figure 6C). Levels of SDF-1 in PRP from WT mice treated with P-selectin antibody $(2.52 \pm 0.24 \mathrm{ng} / \mathrm{mL})$ were significantly decreased, compared with $\operatorname{IgG}(4.32 \pm 0.67$ $\mathrm{ng} / \mathrm{mL}$ ); in $A_{T l a^{-/}}$mice, however, there was no difference in SDF-1 levels in PRP between treatments: P-selectin antibody, $1.95 \pm 0.18 \mathrm{ng} / \mathrm{mL} ; \mathrm{IgG}, 2.43 \pm 0.74 \mathrm{ng} / \mathrm{mL}(P=0.253)$ (Figure 6D). These results suggest that P-selectin-mediated release of VEGF and SDF-1 from platelets enhances lung colony formation, which is dependent on AT1A signaling.
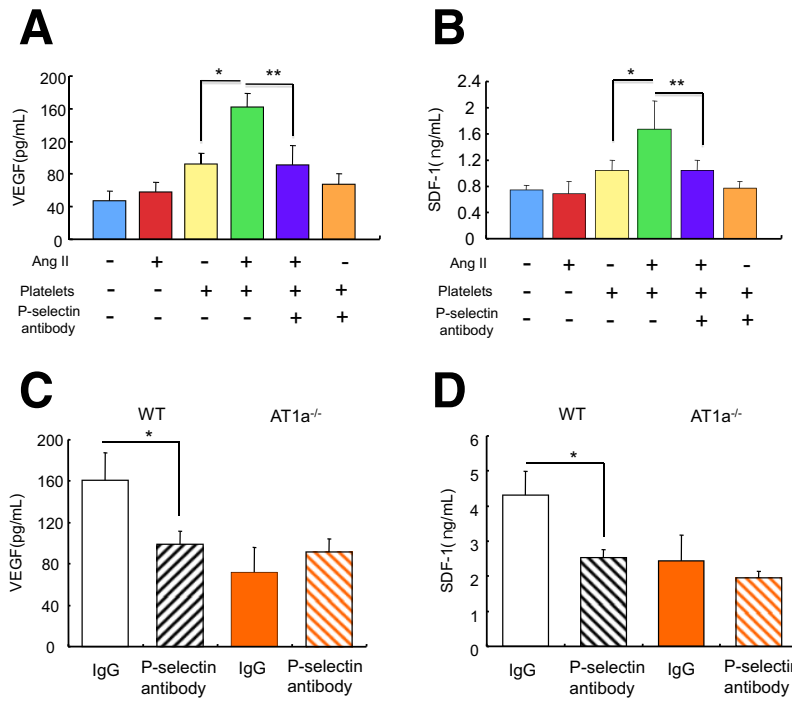

Figure 6 Release of VEGF and SDF-1 from platelets. A and B: Concentrations of VEGF $(\mathbf{A})$ and SDF-1 (B) in culture medium after incubation of platelets with tumor cells. B16F1 cells (six-well tissue culture plates at $3 \times 10^{5}$ cells per well) were incubated with or without platelets $\left(1.0 \times 10^{5}\right.$ per well) and were stimulated with Ang II (10 $\mu \mathrm{g} / \mathrm{mL}$ per well) or P-selectin antibody (10 $\mu \mathrm{g} / \mathrm{mL}$ per well) for 6 hours. Levels of VEGF and SDF-1 in collected medium were measured by ELISA. C and D: Concentration of VEGF (C) and SDF-1 (D) in PRP from WT and $A T 1 a^{-/-}$mice treated with P-selectin antibody or IgG for 7 days after injection of B16F1 cells. Data are expressed as means \pm SD. $n=6$ mice per group. ${ }^{*} P<0.05,{ }^{*} P<0.01$ (A and $\left.\mathbf{B}\right) ;{ }^{*} P<0.05$ versus IgG treated mice (C and D), Student's t-test.

\section{AT1A Signaling Mobilizes CXCR4 ${ }^{+}$VEGFR ${ }^{+}$ Hematopoietic Cells into the Metastatic Area}

The hematopoietic cytokines pro-MMP-9 and SCF were measured. BM levels of pro-MMP-9 and plasma level of $\mathrm{SCF}$ in $A_{T 1 a^{-/-}}$mice $(308 \pm 214 \mathrm{ng} / \mathrm{mL}$ and $158.8 \pm 18.8$ $\mathrm{pg} / \mathrm{mL}$, respectively) on day 7 were lower than those in WT mice $(998 \pm 522 \mathrm{ng} / \mathrm{mL}$ and $214 \pm 17.2 \mathrm{pg} / \mathrm{mL}$, respectively) $(\mathrm{P}<0.05)$ (Figure $7, \mathrm{~A}$ and $\mathrm{B})$.

An increase in hematopoietic cytokines has been reported to mobilize hematopoietic progenitor cells to promote tumor growth, and VEGFR $1^{+}$hematopoietic progenitors are required for the regulation of tumor metastasis. ${ }^{36}$ Therefore, involvement of AT1A signaling in mobilization of CXCR $4^{+}$VEGFR $1^{+}$cells into lung tissue was determined by fluorescence-activated cellsorting analysis. The expression of CXCR $4^{+}$VEGFR $1^{+}$cells on circulating cells on day 5 was reduced in $A T l a^{-1-}$ mice, compared with WT mice: $A T 1 a^{-1-}, 0.273 \pm 0.159$; WT, $1.27 \pm$ $0.173(P<0.05)$ (Figure 7C). To verify mobilization of $\mathrm{CXCR}^{+}{ }^{+}$VEGFR $1^{+}$cells into lung tissue, we performed double immunostaining for CXCR4 and VEGFR1 in lung tissues on day 7. CXCR $4^{+}$VEGFR $1^{+}$cells were located around the metastatic areas in WT mice, but were rarely seen in $A T l a^{-1-}$ mice (Figure 7D). These results suggest that AT1A signaling promotes mobilization of CXCR $4^{+}$VEGFR $1^{+}$cells to the metastatic area.

\section{Transplantation of BM Cells from $A T 1 a^{-/-}$Mice to WT Mice Reduces Lung Colony Formation}

Recruitment of progenitor cells from BM cells is reported to play a crucial role in tumor invasion and metastasis. ${ }^{37}$ To examine the contribution of BM cells expressing AT1A to tumor colony formation, selective deletion of AT1A receptors in BM cells was performed by transplantation of $\mathrm{BM}$ cells from $\mathrm{ATIa}^{-1-}$ mice. Colony formation in lung tissue was reduced in $\mathrm{ATla}^{-/-} \mathrm{BM}$-transplanted WT mice, compared with that in WT-BM-transplanted WT mice: WT to WT, $112.8 \pm 16.2$ colonies; $A T 1 a^{-/-}$to WT, $75.8 \pm 6.8$ colonies $(P<0.05)$ (Figure $8, \mathrm{~A}$ and $\mathrm{B})$. These results suggest that recruitment of BM cells expressing AT1A receptor contributes to colony formation in the lung.

\section{Discussion}

Accumulating molecular and in vivo evidence indicates that the expression and actions of the renin-angiotensin system influence malignancy and also predict that renin-angiotensin system inhibitors, which are currently used to treat hypertension and cardiovascular disease, might augment cancer therapies. ${ }^{12}$ Ang II is reported to function in proliferation, migration, and growth-factor synthesis in several types of vascular cells. ${ }^{13-18}$ We have previously reported that AT1 receptor signaling promotes tumor-associated angiogenesis. $^{21,25}$ Nonetheless, the precise mechanisms of tumor 
A

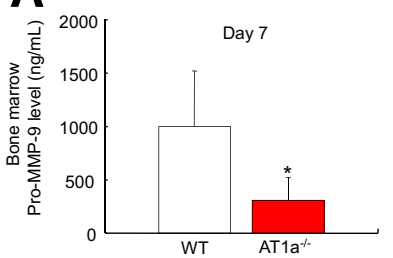

C
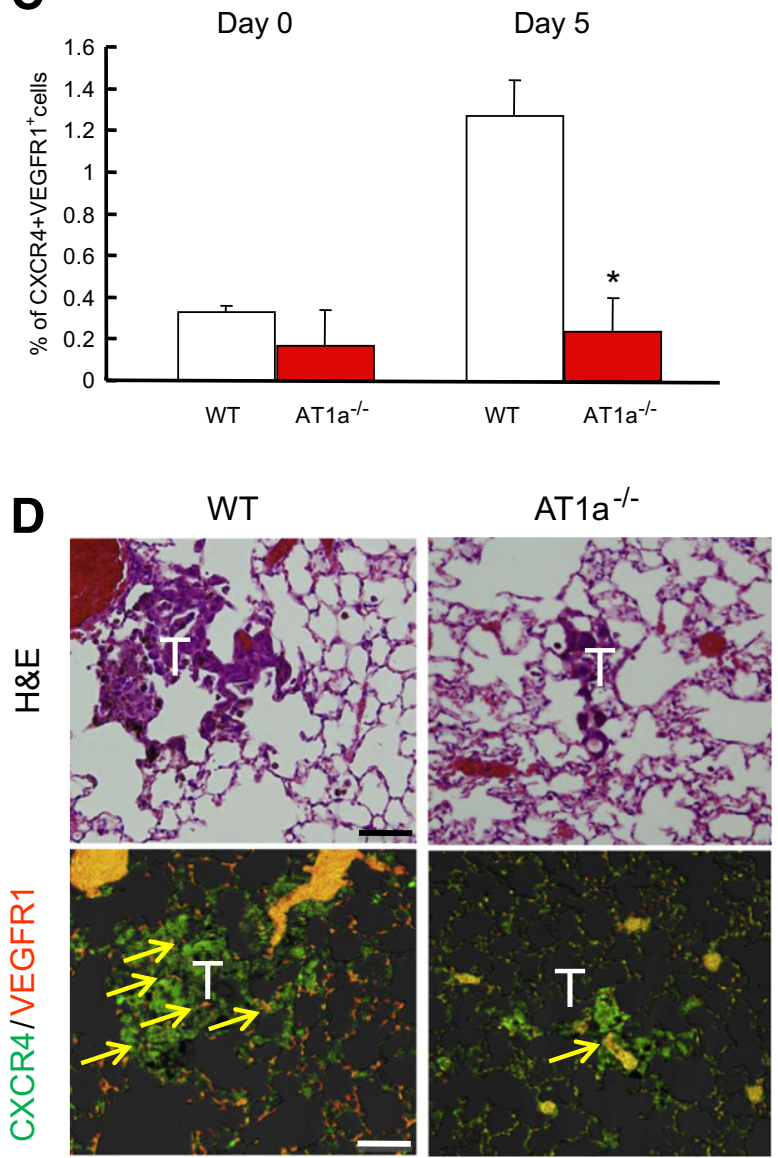

Figure 7 Reduced mobilization of $\mathrm{CXCR} 4^{+} \mathrm{VEGFR}{ }^{+}$cells in peripheral blood and lung tissue in $A T 1 a^{-/-}$mice. A and B: BM levels of pro-MMP-9 (A) and plasma levels of SCF (B) on day 7 after injection of B16F1 cells. C: Percentage of CXCR4 ${ }^{+}$VEGFR $1^{+}$cells in the peripheral blood on days 0 and 5 . D: Mobilization of CXCR4 ${ }^{+}$VEGFR $1^{+}$cells to lung tissue on day 7 after injection of B16F1 cells is suppressed in $A T 1 a^{-/-}$mice. H\&E staining (top row) corresponds to double immunostaining (bottom row) of lung sections from WT and $A T 1 a^{-1-}$ mice with antibodies against CXCR4 (green) and VEGFR1 (red). The metastatic area is marked as tumor (T). Double-labeled cells are indicated by arrows. Images are representative of three independent samples. Data are expressed as means \pm SD. $n=5$ mice per group. ${ }^{*} P<0.05$ versus WT $(\mathbf{A}-\mathbf{C})$, Student's $t$-test $(\mathbf{A}-\mathbf{C})$. Scale bar $=100 \mu \mathrm{m}$.

development, especially regarding tumor metastasis, are not yet completely understood.

Platelets are small, specialized blood cells that are released as anuclear cytoplasmic bodies from megakaryocytes in the $\mathrm{BM}$. The main function of platelets is, as activated platelets, to halt hemorrhage after tissue trauma and vascular injury. ${ }^{38,39}$ Platelets contribute to critical steps in cancer metastasis by facilitating tumor cell migration, invasion, and arrest within the vasculature. ${ }^{4,5}$ Direct platelet-tumor cell contact promotes tumor cell adhesion to endothelial cells, enhancing extravasation into tissues and formation of metastasis deposits. ${ }^{4}$ Tumor cells contain various membrane receptors that can bind directly to platelets and mediate tumor cell-platelet binding and activate platelets. The strongly activated platelets increase surface expression of CD40L, tumor necrosis factor ligand superfamily member 14 (TNFSF14), and P-selectin, as well as secretion of potent inflammatory substances, such as IL-1 $\beta$ and platelet factor $4{ }^{40}$ To get some insight into the underlying mechanisms by which AT1A signaling promotes tumor metastasis, we focused on the interaction of platelets and tumor cells during the formation of tumor metastasis.

The present results show that endogenous AT1A signaling promoted tumor metastasis through P-selectin-mediated platelet adhesion to metastatic tumor cells and endothelial cells in lung tissue. P-selectin (CD62P) is one of the adhesion molecules expressed on the platelet surface and its expression increases when platelets are activated. ${ }^{41}$ We have previously reported that P-selectin-mediated platelet adhesion to the vessel wall appears to be a key event in local angiogenesis. ${ }^{42}$ P-selectin seems to be involved in cancer as well, because P-selectin knockout mice show a significant reduction in tumor and tumor metastasis formation. ${ }^{43,44}$ Ang II is reported to induce an early phase of platelet activation in healthy volunteers. ${ }^{45}$ In the present study, flow cytometry analysis revealed that Ang II induced the expression of P-selectin on platelets from WT mice, but not on those from $A T 1 a^{-1-}$

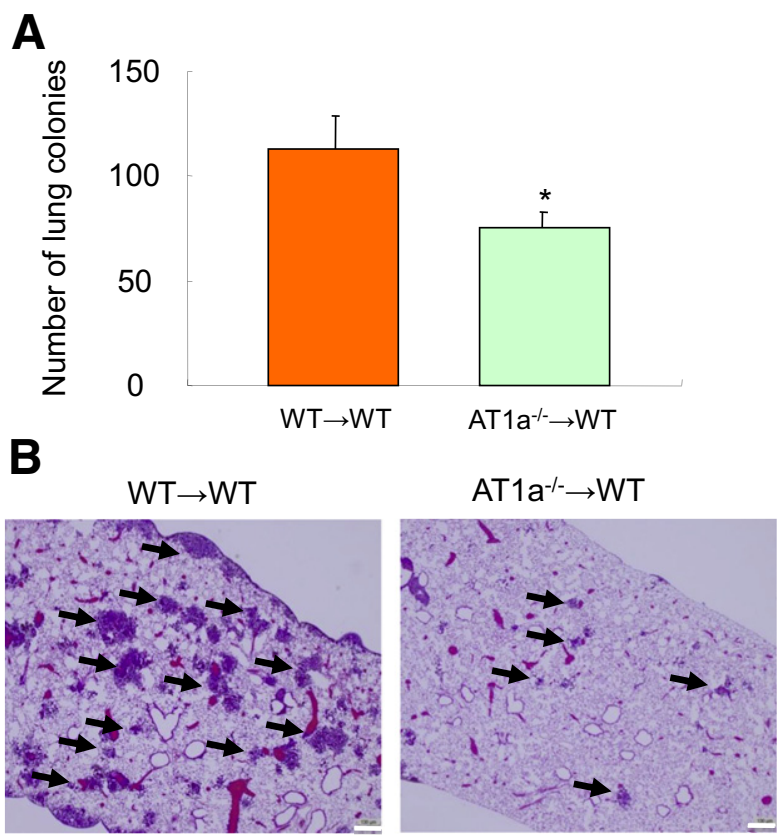

Figure 8 Effect of AT1A signaling on lung colony formation after BM transplantation. A: Number of metastatic lung colonies after transplantation of BM cells from WT or $A T 1 a^{-/-}$mice to WT. B: Typical histological appearance of lung metastasis (arrows). Data are expressed as means \pm SD. $n=5$ mice per group. ${ }^{\star} P<0.05$ versus WT-WT transplantation. Scale bar $=130 \mu \mathrm{m}$. 
mice. Furthermore, immunofluorescent analysis revealed that accumulated P-selectin-positive platelets in metastatic tumor was attenuated in $\mathrm{ATla}^{-1-}$ mice. These results suggest that the Ang II-AT1A signaling pathway plays a role in platelet activation in the process of tumor metastasis.

The expression of P-selectin is induced not only on platelets, but also on endothelial cells, which in an experimental model would contribute to lung metastasis. ${ }^{44}$ In the present study, Ang II enhanced the expression of P-selectin on platelets; however, it reduced expression on endothelial cells (Figure 4), suggesting that P-selectin on platelets appears to be involved in tumor metastasis in this model. Activated platelets swell and adhere to tumor and endothelial cells in the initial colony formation step. Because PSGL-1 is a ligand for P-selectin, we confirmed that Ang II induced expression of PSGL-1 on tumor cells as well as on endothelial cells. Moreover, expression of PSGL-1 in lung tissue on day 7 after tumor injection was significantly reduced in $\mathrm{ATla}^{-/-}$mice. These results suggest that platelets bind to tumor cells and endothelial cells mediated by P-selectin-PSGL-1 interactions during the evolution of tumor metastasis.

To clarify whether enhanced P-selectin on platelets through AT1A signaling contributes to metastasis formation, mice were treated with a neutralizing antibody against P-selectin. Tumor metastasis formation was significantly inhibited by injection of P-selectin antibody in WT but not in $\mathrm{ATla}^{-/-}$mice (Figure 3B). These results suggest that AT1A signaling-dependent enhancement of P-selectin is involved in pulmonary melanoma metastasis.

In addition, it has been suggested that platelet activation is crucial for capturing platelets by colon carcinoma cells, and that the blockade of platelet P-selectin expression represses the extent of platelet-tumor cell complex formation. ${ }^{46,47}$ The present study also revealed that blockade of P-selectin suppressed platelet adhesion to pulmonary metastasis tumors in WT but not in $A T l a^{-1-}$ mice. These results suggest that lung colony formation is caused by P-selectin-mediated interaction of platelets with tumor cells and that AT1A signaling plays a critical role in the P-selectin-mediated platelet attachment to the metastatic tumor locus.

Platelets contain many proangiogenic growth factors, including proangiogenic factors (eg, VEGF-A and SDF-1) that are involved in tumor metastasis development. ${ }^{9}$ In the present study, treatment with neutralizing antibodies specific for VEGF and CXCR4, a receptor for SDF-1, inhibited lung colony formation in WT but not in $A T I a^{-/}$mice, indicating that AT1A signaling is crucial for tumor metastasis, which is dependent on VEGF and SDF-1 release. In addition, AT1A signaling regulated the release of VEGF-A and SDF-1 from platelets at the site of tumor metastasis (Figure 5). Furthermore, Ang II released VEGF and SDF-1 from platelets through interaction with tumor cells in vitro (Figure 6). AT1A signaling played a role in P-selectin-mediated VEGF and SDF-1 release from platelets. Recent evidence, including ours, shows that
VEGF-A and SDF-1 released from platelets promote angiogenesis during vascular injury and tumor metastasis. ${ }^{9}$ In the present model, therefore, AT1A signaling is required for tumor colonization, through its release of VEGF and SDF-1 from platelets interacting with tumor cells.

In addition to VEGF and SDF-1, other hematopoietic growth factors (including SCF through MMP-9 activation) are responsible for mobilization of BM-derived VEGFR $1^{+}$ progenitor cells relevant to angiogenesis. ${ }^{9,48,49}$ VEGF and SDF-1 from platelets promote tumor growth and metastasis though mobilization of BM-derived hematopoietic and endothelial progenitor cells. ${ }^{49}$ In thrombocytopenic mice, SDF-1 plasma elevation is severely impaired, as is mobilization of proangiogenic CXCR $4^{+}$VEGFR $1^{+}$cells and tissue revascularization. ${ }^{9}$ In accord, in the present study increased levels of MMP-9 and SCF were associated with mobilization of CXCR $4^{+}$VEGFR $1^{+}$cells. VEGF and SDF-1, delivered from activated platelets, are also important factors for the activation of MMP-9 in BM and the subsequent mobilization of VEGFR $1^{+}$myelomonocytic cells. ${ }^{50}$ The present results also show that AT1A signaling facilitates mobilization of CXCR $4{ }^{+}$VEGFR $1^{+}$cells from BM to peripheral blood, as well as recruitment of hemangiocytes expressing CXCR $4^{+}$VEGFR $1^{+}$to lung tissue during the evolution of pulmonary metastasis. Transplantation of $A T 1 a^{-/-}$BM cells to WT mice suppressed colony formation, compared with transplantation of WT BM cells to WT mice. These results confirm that AT1A signaling on the BM-derived cells is essential for tumor metastasis.

In conclusion, the present study indicates that AT1A signaling plays a critical role in tumor metastasis through P-selectin-mediated interactions of activated platelets with

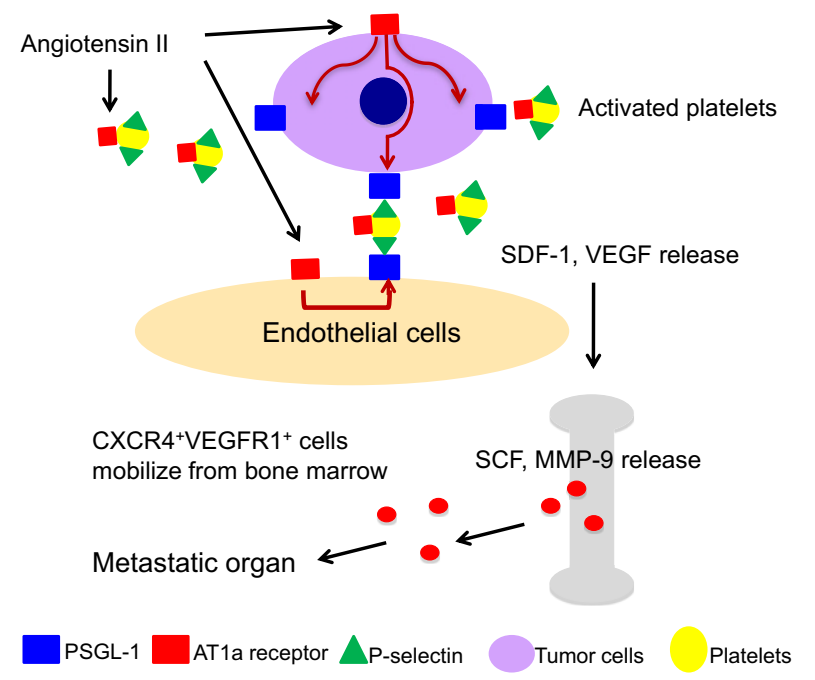

Figure 9 Model of the role of AT1A signaling in the enhancement of tumor colony formation. AT1A signaling up-regulates the expression of P-selectin on platelets and of PSGL-1 on metastatic tumor cells and endothelial cells in the target tissue. These enhanced adhesion molecules induce interaction of platelets with tumor cells and endothelial cells during the initial course of tumor metastasis. VEGF and SDF-1 delivered from accumulated platelets induce mobilization and recruitment of hemangiocytes expressing CXCR4 and VEGFR1 in lung tissue, leading to tumor metastasis. 
tumor cells and endothelial cells, and via the AT1A signaling-dependent production of VEGF and SDF-1, involved in mobilization of hematopoietic cells expressing CXCR $4{ }^{+}$VEGFR $1^{+}$from BM to facilitate the establishment of tumor colonization (Figure 9). Highly selective AT1A antagonists may therefore become a useful therapeutic tool for cancer treatment.

\section{Acknowledgments}

We thank Michiko Ogino, Kyoko Yoshikawa, and Mieko Hamano for their technical assistance and Robert E. Brandt (MedEd Japan) for assistance in editing and manuscript preparation.

\section{References}

1. Fidler IJ: The pathogenesis of cancer metastasis: the seed and soil hypothesis revisited. Nat Rev Cancer 2003, 3:453-458

2. Joyce JA, Pollard JW: Microenvironmental regulation of metastasis. Nat Rev Cancer 2009, 9:239-252

3. Chaffer CL, Weinberg RA: A perspective on cancer cell metastasis. Science 2011, 331:1559-1564

4. Mehta P: Potential role of platelets in the pathogenesis of tumor metastasis. Blood 1984, 63:55-63

5. Trikha M, Nakada MT: Platelets and cancer: implications for antiangiogenic therapy. Semin Thromb Hemost 2002, 28:39-44

6. English D, Garcia JG, Brindley DN: Platelet-released phospholipids link haemostasis and angiogenesis. Cardiovasc Res 2001, 49:588-599

7. Sierko E, Wojtukiewicz MZ: Platelets and angiogenesis in malignancy. Semin Thromb Hemost 2004, 30:95-108

8. Gunsilius E, Petzer A, Stockhammer G, Nussbaumer W, Schumacher P, Clausen J, Gastl G: Thrombocytes are the major source for soluble vascular endothelial growth factor in peripheral blood. Oncology 2000, 58:169-174

9. Jin DK, Shido K, Kopp HG, Petit I, Shmelkov SV, Young LM, Hooper AT, Amano H, Avecilla ST, Heissig B, Hattori K, Zhang F, Hicklin DJ, Wu Y, Zhu Z, Dunn A, Salari H, Werb Z, Hackett NR, Crystal RG, Lyden D, Rafii S: Cytokine-mediated development of SDF-1 induces revascularization through recruitment of CXCR4+ hemangiocytes, [Erratum appeared in Nat Med 2006, 12:978]. Nat Med 2006, 12:557-567

10. van den Dolder J, Mooren R, Vloon AP, Stoelinga PJ, Jansen JA: Platelet-rich plasma: quantification of growth factor levels and the effect on growth and differentiation of rat bone marrow cells. Tissue Eng 2006, 12:3067-3073

11. Ibrahim J, Hughes AD, Sever PS: Action of angiotensin II on DNA synthesis by human saphenous vein in organ culture. Hypertension 2000, 36:917-921

12. George AJ, Thomas WG, Hannan RD: The renin-angiotensin system and cancer: old dog, new tricks. Nat Rev Cancer 2010, 10:745-759

13. Tamarat R, Silvestre T, Durie M, Levy BI: Angiotensin II angiogenic effect in vivo involves vascular endothelial growth factor- and inflammation-related pathways. Lab Invest 2002, 82:747-756

14. Bell L, Madri JA: Influence of the angiotensin system on endothelial and smooth muscle cell migration. Am J Pathol 1990, 137:7-12

15. Sasaki K, Murohara T, Ikeda H, Sugaya T, Shimada T, Shintani S, Imaizumi T: Evidence for the importance of angiotensin II type 1a receptor in ischemia-induced angiogenesis. J Clin Invest 2002, 109:603-611

16. Tufan H, Zaki BM, Tecder-Unal M, Erdem SR, Take G: Angiotensin II captopril cotreatment augments angiogenesis in abdominal skin flap in rats. Ann Plast Surg 2007, 58:441-448
17. Muramatsu M, Katada J, Hayashi I, Majima M: Chymase as a proangiogenic factor. A possible involvement of chymase-angiotensindependent pathway in the hamster sponge angiogenesis model. J Biol Chem 2000, 275:5545-5552

18. Katada J, Muramatsu M, Hayashi I, Tsutsumi M, Konishi Y, Majima M: Significance of vascular endothelial cell growth factor upregulation mediated via a chymase-angiotensin-dependent pathway during angiogenesis in hamster sponge granulomas. J Pharmacol Exp Ther 2002, 302:949-956

19. Kim S, Iwao H: Molecular and cellular mechanisms of angiotensin II-mediated cardiovascular and renal diseases. Pharmacol Rev 2000, 52:11-34

20. Egami K, Murohara T, Shimada T, Sasaki K, Shintani S, Sugaya T, Ishii M, Akagi T, Ikeda H, Matsuishi T, Imaizumi T: Role of host angiotensin II type I receptor in tumor angiogenesis and growth. J Clin Invest 2003, 112:67-75

21. Fujita M, Hayashi I, Yamashina S, Fukamizu A, Itoman M, Majima M: Angiotensin type 1a receptor signaling-dependent induction of vascular endothelial growth factor in stroma is relevant to tumorassociated angiogenesis and tumor growth. Carcinogenesis 2005, 26: 271-279

22. Uemura $H$, Ishiguro $H$, Nagashima $Y$, Sasaki $T$, Nakaigawa $N$, Hasumi H, Kato S, Kubota Y: Antiproliferative activity of angiotensin II receptor blocker through cross talk between stromal and epithelial prostate cancer cells. Mol Cancer Ther 2005, 4:1699-1709

23. Miyajima A, Koasaka T, Asano T, Asano T, Seta K, Kawai T, Hayakawa M: Angiotensin II type I antagonist prevent pulmonary metastasis of murine renal cancer by inhibiting tumor angiogenesis. Cancer Res 2002, 62:4176-4179

24. Fujimito Y, Sasaki T, Tsuchida A, Chayama K: Angiotensin II type 1 receptor expression in human pancreatic cancer and growth inhibition by angiotensin II type 1 receptor antagonist. FEBS Lett 2001, 495 : 197-200

25. Fujita M, Hayashi I, Yamashina S, Itoman M, Majima M: Blockade of angiotensin AT1a receptor signaling reduces tumor growth, angiogenesis, and metastasis. Biochem Biophys Res Commun 2002, 294:441-447

26. Senchenkova EY, Russell J, Almeida-Paula LD, Harding JW, Granger DN: Angiotensin II-mediated microvascular thrombosis. Hypertension 2010, 56:1089-1095

27. Alexandru N, Popov D, Dragan E, Andrei E, Georgescu A: Platelet activation in hypertension associated with hypercholesterolemia: effects of irbesartan. J Thromb Haemost 2011, 9:173-184

28. Ishikawa M, Sekizuka E, Yamaguchi N, Nakadate H, Terao S, Granger DN, Minamitani H: Angiotensin II type 1 receptor signaling contributes to platelet-leukocyte-endothelial cell interactions in the cerebral microvasculature. Am J Physiol Heart Circ Physiol 2007, 292: $\mathrm{H} 2306-\mathrm{H} 2315$

29. Matsui Y, Amano H, Ito Y, Eshima K, Suzuki T, Ogawa F, Iyoda A, Satoh Y, Kato S, Nakamura M, Kitasato H, Narumiya S, Majima M: Thromboxane A2 receptor signaling facilitates tumor colonization through P-selectin-mediated interaction of tumor cells with platelets and endothelial cells. Cancer Sci 2012, 103:700-707

30. Amano H, Ito Y, Suzuki T, Kato S, Matsui Y, Ogawa F, Murata T, Sugimoto Y, Senior R, Kitasato H, Hayashi I, Satoh Y, Narumiya S, Majima M: Roles of a prostaglandin E-type receptor, EP3, in upregulation of matrix metalloproteinase-9 and vascular endothelial growth factor during enhancement of tumor metastasis. Cancer Sci 2009, 100: $2318-2324$

31. Hattori K, Hessig B, Wu Y, Dias S, Tejada R, Ferris B, Hicklin DJ, Zhu Z, Bohlen P, Witte L, Hendrikx J, Hackett NR, Crystal RG, Moore MA, Werb Z, Lyden D, Rafii S: Placental growth factor reconstitutes hematopoiesis by recruiting VEGFR $1(+)$ stem cells from bone-marrow microenvironment. Nat Med 2002, 8:841-849

32. Eshima K, Suzuki H, Shinohara N: Cross-positive selection of thymocytes expressing a single TCR by multiple major histocompatibility complex molecules of both classes: implications for CD4+ versus CD8+ lineage commitment. J Immunol 2006, 176:1628-1636 
33. Katoh H, Hosono K, Ito Y, Suzuki T, Ogawa Y, Kubo H, Kamata H, Mishima T, Tamaki H, Sakagami H, Sugimoto Y, Narumiya S, Watanabe M, Majima M: COX-2 and prostaglandin EP3/EP4 signaling regulate the tumor stromal proangiogenic microenvironment via CXCL12-CXCR4 chemokine systems. Am J Pathol 2010, 176: $1469-1483$

34. Hosono K, Suzuki T, Tamaki H, Sakagami H, Hayashi I, Narumiya S, Alitalo K, Majima M: Roles of prostaglandin E2-EP3/EP4 receptor signaling in the enhancement of lymphangiogenesis during fibroblast growth factor-2-induced granulation formation. Arterioscler Thromb Vasc Biol 2011, 31:1049-1058

35. Ogawa Y, Suzuki T, Oikawa A, Hosono K, Kubo H, Amano H, Ito Y, Kitasato H, Hayashi I, Kato T, Sugimoto Y, Narumiya S, Watanabe M, Majima M: Bone marrow-derived EP3-expressing stromal cells enhance tumor-associated angiogenesis and tumor growth. Biochem Biophys Res Commun 2009, 382:720-725

36. Kaplan RN, Riba RD, Zacharoulis S, Bramley AH, Vincent L, Costa C, MacDonald DD, Jin DK, Shido K, Kerns SA, Zhu Z, Hicklin D, Wu Y, Port JL, Altorki N, Port ER, Ruggero D, Shmelkov SV, Jensen KK, Rafii S, Lyden D: VEGFR1-positive haematopoietic bone marrow progenitors initiate the pre-metastatic niche. Nature 2005, 438:820-827

37. Lyden D, Hattori K, Dias S, Costa C, Blaikie P, Butros L, Chadburn A, Heissig B, Marks W, Witte L, Wu Y, Hicklin D, Zhu Z, Hackett NR, Crystal RG, Moore MA, Hajjar KA, Manova K, Benezra R, Rafii S: Impaired recruitment of bone-marrow-derived endothelial and hematopoietic precursor cells blocks tumor angiogenesis and growth. Nat Med 2001, 7:1194-1201

38. Ruggeri ZM, Mendolicchio GL: Adhesion mechanism in platelet function. Circ Res 2007, 100:1673-1685

39. Davì G, Patrono C: Platelet activation and atherothrombosis. N Engl J Med 2007, 357:2482-2494

40. Nurden AT: Platelets, inflammation and tissue regeneration. Thromb Haemost 2011, 105(Suppl 1):S13-S33

41. Vandendries ER, Furie BC, Furie B: Role of P-selectin and PSGL-1 in coagulation and thrombosis. Thromb Haemost 2004, 92:459-466
42. Kato S, Amano H, Ito $\mathrm{Y}$, Eshima K, Aoyama N, Tamaki H, Sakagami H, Satoh Y, Izumi T, Majima M: Effect of erythropoietin on angiogenesis with the increased adhesion of platelets to the microvessels in the hind-limb ischemia model in mice. J Pharmacol Sci 2010, 112:167-175

43. Ludwig RJ, Boehme B, Podda M, Henschler R, Jagner E, Tandi C, Boehncke WH, Zollner TM, Kaufmann R, Gille J: Endothelial P-selectin as a target of heparin action in experimental melanoma lung metastasis. Cancer Res 2004, 64:2743-2750

44. Kim YJ, Borsig L, Varki NM, Varki A: P-selectin deficiency attenuates tumor growth and metastasis. Proc Natl Acad Sci USA 1998, 95: 9325-9330

45. Larsson PT, Schwieler JH, Wallén NH: Platelet activation during angiotensin II infusion in healthy volunteers. Blood Coagul Fibrinolysis 2000, 11:61-69

46. Kohler S, Ullrich S, Richter U, Schumacher U: E-/P-selectin and colon carcinoma metastasis: first in vivo evidence for their crucial role in clinically relevant model of spontaneous metastasis formation in lung. Br J Cancer 2010, 102:602-609

47. Möhle R, Green D, Moore MA, Nachmann RL, Rafii S: Constitutive production and thrombin-induced release of vascular endothelial growth factor by human megakaryocytes and platelets. Proc Natl Acad Sci USA 1997, 94:663-668

48. Petit I, Jin D, Rafii S: The SDF-1-CXCR4 signaling pathway: a molecular hub modulating neo-angiogenesis. Trends Immunol 2007 , 28:299-307

49. Rafii DC, Psaila B, Butler J, Jin DK, Lyden D: Regulation of vasculogenesis by platelet-mediated recruitment of bone marrow-derived cells. Arterioscler Thromb Vasc Biol 2008, 28:217-222

50. Massberg S, Konrad I, Schürzinger K, Lorenz M, Schneider S, Zohlnhoefer D, Hoppe K, Schiemann M, Kennerknecht E, Sauer S, Schulz C, Kerstan S, Rudelius M, Seidl S, Sorge F, Langer H, Peluso M, Goyal P, Vestweber D, Emambokus NR, Busch DH, Frampton J, Gawaz M: Platelets secrete stromal cell-derived factor 1 alpha and recruit BM-derived progenitor cells to arterial thrombi in vivo. J Exp Med 2006, 203:1221-1233 